\title{
The Architectural Element Distribution of Cinambo Formation in Jatigede Area, Sumedang District, West Java - Indonesia
}

\author{
Yan Rizal $^{1}$ \& Aji Rahmat Gumilar ${ }^{2}$ \\ ${ }^{1}$ Geological Department of Bandung Institute of Technology, Jalan Ganesha 10 Bandung, Indonesia \\ ${ }^{2}$ Pertamina Cirebon, Jalan Raya Klayan Cirebon, Indonesia \\ Correspondence: Yan Rizal, Geological Department of Bandung Institute of Technology, Jalan Ganesha 10 \\ Bandung, Indonesia. Tel: 62-821-1638-2176. E-mail: yan@gl.itb.ac.id
}

Received: April 9, 2019

doi:10.5539/mas.v13n7p94
Accepted: May 23, 2019

Online Published: June 30, 2019

URL: https://doi.org/10.5539/mas.v13n7p94

\begin{abstract}
This research is conducted in Jatigede subdistrict, Sumedang district, West Java Province, Indonesia, with a geographic position $175500-185000 \mathrm{E}$ and $9237800-9242200 \mathrm{~S}$. There are many different types of rocks scattered forming the Cinambo Formation including sandstones, mudstones, alternation claystones, conglomeratic sandstones, and conglomerate stones. Stratigraphic cross-section measurements on the Cimanuk River and Cinambo River traverses is carried out to figure out the distribution of the architectural elements of the Cinambo Formation. Nine lithofacies are obtained from both traverses: massive conglomerate (A1-1), graded bedding conglomerate and graded bedding conglomeratic sandstone (A2-3), conglomeratic sandstone (A2-1), massive sandstone (B1-1), graded bedding sandstone (B2-4), bedded sandstone (B2-1), alternation sandstone - mudstone (sandstone domination) (C2-2), alternation dense and thin alternation sandstone - mudstone, and mudstone intercalation sandy siltstone. The architectural elements that appear on Cimanuk River traverse are sandy lobe, proximal channel, distributary channel and proximal levee, while the elements that appear on the Cinambo River traverse are sandy lobe, proximal levee and distal levee. A vertical change of the architectural element can be observed on both traverses, which are likely to be caused by the fluctuation of sea level. Base on the architectural element data, it can be concluded that the Cinambo Formation was deposited in the upper fan-basin plain of a deep-marine fan system.
\end{abstract}

Keywords: cinambo formation, turbidite, deep marine sediments, architectural element

\section{Introduction}

In general, if we talk about turbidite deposits, especially in Indonesia, it is still a very interesting study to be studied further, until now there are still many problems related to turbidite deposits that have not been resolved. On the island of Java itself, starting from West Java to East Java, there are very many turbidite deposits during Miocene to Pliocene. Some of them in West Java and Central Java have been investigated by Rizal et al $(2016,2017)$ and Praptisih et al (2012) explain the sedimentation facies of turbidite deposits aged Mio-Pliocene, and Rizal (2018) explain the relationship the relationship of turbidite deposits with hydrocarbon reservoir potential. Deep sea sediments generally have the potential for hydrocarbon systems, as they have been proven in the Kutei Basin, Brunei, Tarakan, North Sumatra, East Java, and Palawan Basin (Kusumastuti et al., 2001) and the Bintuni Basin (Nugrahanto et al., 2001).

Geological research in this area with the characteristics of sediments that are the same as the deposits mentioned above and becomes important for further studies, especially in relation to the potential of hydrocarbons. The results of the study can be used as a reference for the initial study. This study was carried out in the context of identifying turbidite deposits of Mio-Pliocene age on Java. The study area is located in Jatigede, Sumedang district, West Java Province-Indonesia, which is located at a geographic position of $175500-185000 \mathrm{E}$ and $9237800-9242200 \mathrm{~S}$ (Figure 1). 


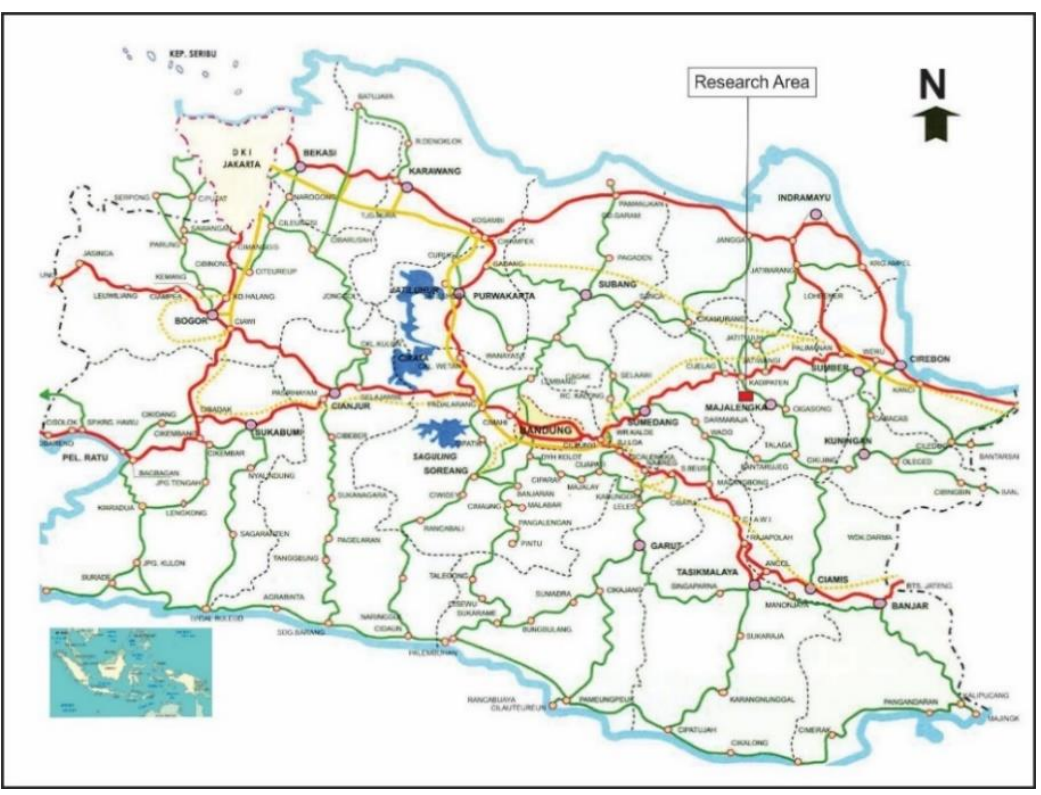

Figure 1. Location map of the study area

The study area resides in the Arjawinangun sheet geological map (Djuri, 1973). According to Martodjojo (1984), this area is a part of Bogor basin. The sedimentary rock found in Bogor Basin consists mostly of turbidite sediment (Koesomadinata and Martodjojo, 1974), which is deposited in a fan system of deep-marine (Martodjojo, 1984). The stratigraphy of Sumedang area and its surrounding has been previously investigated by various researchers such as Bemmelen (1949), Djuri (1973), Martodjojo (1984), and Djuhaeni and Martodjojo (1988) (Figure 2). According to Djuhaeni and Martodjojo (1988), the stratigraphy of the study area comprises of Cisaar Formation, Cinambo Formation, Cantayan Formation, Bantarujeg Formation, Subang Formation, Kaliwangu Formation, and Citalang Formation (Figure 3).

\begin{tabular}{|c|c|c|c|c|c|c|c|}
\hline \multicolumn{3}{|c|}{ Age } & \multirow{2}{*}{\multicolumn{2}{|c|}{$\begin{array}{l}\text { Djuri } \\
\text { (1973) }\end{array}$}} & \multirow{2}{*}{$\begin{array}{l}\text { Martodjojo } \\
\quad(1984)\end{array}$} & \multirow{2}{*}{\multicolumn{2}{|c|}{$\begin{array}{c}\text { Djuhaeni \& } \\
\text { Martodjojo } \\
\text { (1989) }\end{array}$}} \\
\hline \multicolumn{2}{|c|}{ Period } & $\begin{array}{c}\text { Blow Zonation } \\
(1970)\end{array}$ & & & & & \\
\hline \multirow{3}{*}{\multicolumn{2}{|c|}{ Pleistocene }} & N 23 & \multicolumn{2}{|c|}{ Young Volc. Product } & \multirow{2}{*}{$\begin{array}{l}\text { Volcanic Breccia } \\
\text { Citalang Formation }\end{array}$} & \multirow{2}{*}{\multicolumn{2}{|c|}{$\begin{array}{l}\text { Volcanic Breccia } \\
\text { Citalang Formation }\end{array}$}} \\
\hline & & N 22 & \multicolumn{2}{|c|}{ Old Volc. Product } & & & \\
\hline \multirow{4}{*}{\multicolumn{2}{|c|}{ Pliocene }} & N 21 & \multirow{2}{*}{\multicolumn{2}{|c|}{$\underbrace{\text { Tilted Breccia }}_{\text {Citalang Formation }}$}} & \multirow{3}{*}{$\begin{array}{l}\text { Kaliwangu } \\
\text { Formation }\end{array}$} & \multirow{2}{*}{\multicolumn{2}{|c|}{$\begin{array}{l}\text { Kaliwangu } \\
\text { Formation }\end{array}$}} \\
\hline & & N 20 & & & & & \\
\hline & & N 19 & \multirow{3}{*}{\multicolumn{2}{|c|}{ Kuliwangu Formation }} & & \multicolumn{2}{|c|}{ Subang Formation } \\
\hline & & N 18 & & & \multirow{7}{*}{ 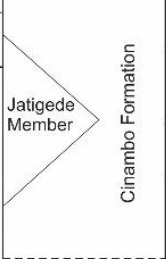 } & Bantarujeg & \\
\hline \multirow{12}{*}{$\begin{array}{l}\stackrel{0}{c} \\
\text { d } \\
\stackrel{0}{\Sigma} \\
\text { ¿ }\end{array}$} & \multirow{2}{*}{$\stackrel{\Xi}{\Xi}$} & $\mathrm{N} 17$ & & & & & 美里 \\
\hline & & $\mathrm{N} 16$ & Upper Member & & & Formation & Еే \\
\hline & \multirow{7}{*}{$\begin{array}{l}\frac{0}{\bar{y}} \\
\frac{\bar{g}}{\Sigma}\end{array}$} & N 15 & \multirow{7}{*}{$\begin{array}{l}\text { Lower } \\
\text { Member }\end{array}$} & \multirow{7}{*}{ 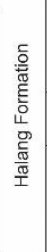 } & & Cinambo & \\
\hline & & $\mathrm{N} 14$ & & & & Formation & \\
\hline & & $\mathrm{N} 13$ & & & & \multirow{5}{*}{\multicolumn{2}{|c|}{ Cisaar Formation }} \\
\hline & & $\mathrm{N} 12$ & & & & & \\
\hline & & N 11 & & & \multirow{6}{*}{ Unexposed } & & \\
\hline & & $\mathrm{N} 10$ & & & & & \\
\hline & & N 9 & & & & & \\
\hline & \multirow{3}{*}{$\begin{array}{l}\text { 촌 } \\
\text { யँ }\end{array}$} & N 8 & \multirow{3}{*}{ Upper Member } & \multirow{3}{*}{ 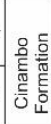 } & & \multirow{3}{*}{\multicolumn{2}{|c|}{ Unexposed }} \\
\hline & & N7 & & & & & \\
\hline & & N 6 & & & & & \\
\hline
\end{tabular}

Figure 2. Stratigraphy compilation of the study area based on previous researchers 


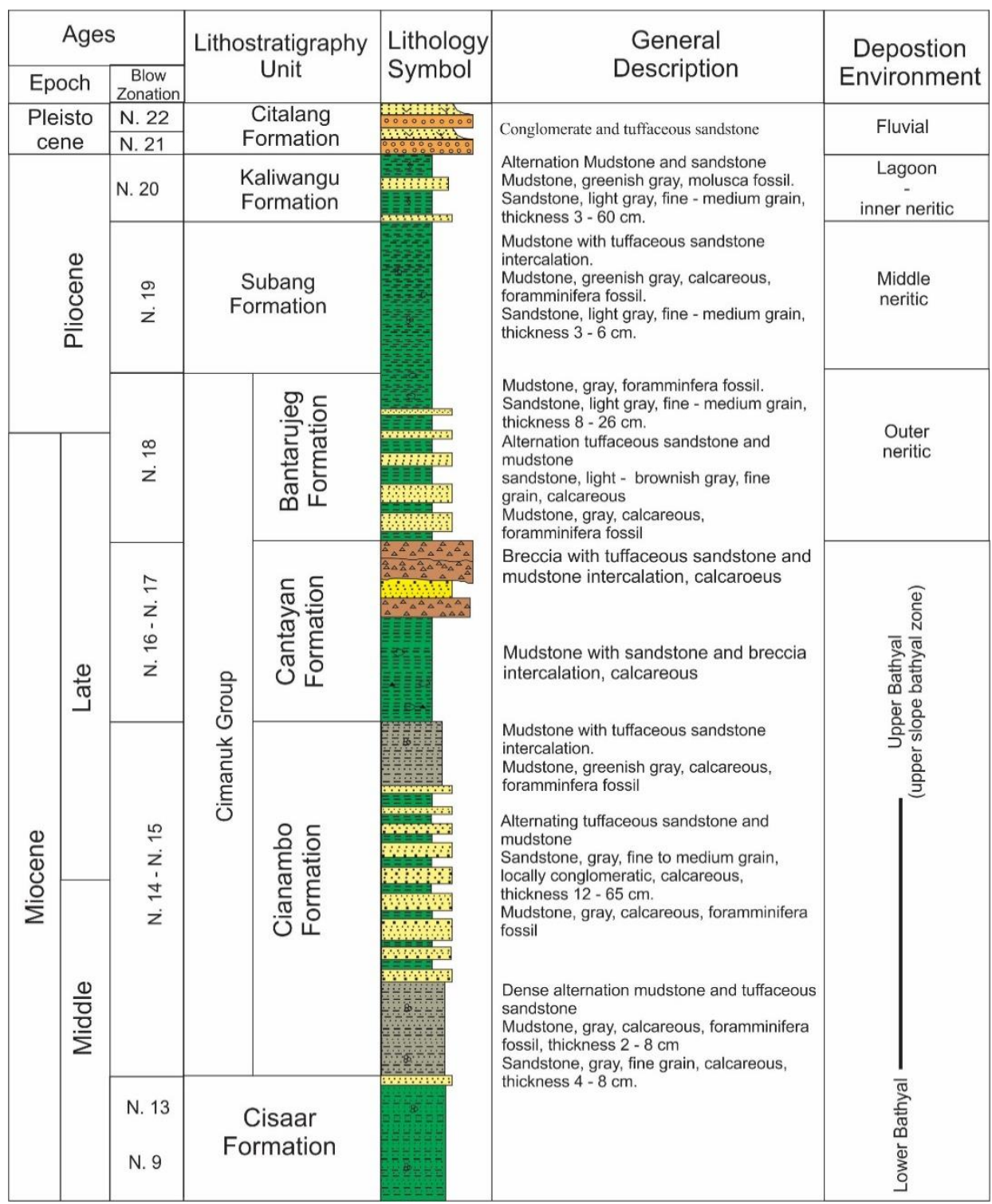

Figure 3. General stratigraphy of the study area (Djuhaeni and Martodjojo, 1988)

This study was conducted specifically on Cinambo Formation, which was conformable above the Cisaar Formation (Figure 3). Djuhaeni and Martodjojo (1988) divided the Cinambo Formation based on the thickness of the layer and the sand-mud ratio, into three parts:

- The lower part comprises of the alternation of calcareous mudstone and tuffaceous sandstone, with its layer thickness varying between 2-6 and a 1:1 to $1: 3$ sand - mud ration, as well as a T.bc and T.bcd sediment structure of the Bouma sequence.

- The middle part comprises of the alternation of tuffaceous sandstone and calcareous mudstone. The sandstone is thicker than that of the lower part, with thickness varying between 10-75 cm, and a 3:1 to 5:1 sand - mud ratio. Sedimentary structures that develops in this segment are the T.abc sequences of Bouma and the Flute Cast at base of the sandstone layer.

- The upper part of the Cinambo Formation comprises of the alternation of calcareous mudstone and tuffaceous mudstone, with sandstone thickness varying between 8-24 cm and a 1:3 sand-mud ratio, with calcareous mudstone and sandstone intercalation building upwards.

The Cinambo Formation is deep-sea fan deposition system is mostly a result of gravity flow (Middleton and Hampton, 1976) where turbidite is also a component aside from non-cohesive debris flow and cohesive debris flow. 
Therefore, the approach taken in this study in understanding the characteristics of the Cinambo Formation is to analyze its lithofacies, which is then expressed descriptively based on field observations, and is then grouped into architectural elements as a part of an interpretive analysis.

\section{Methods}

The study is based on the field-works around the area, with a focus on the area around Cimanuk River and Cinambo River, Sumedang (Figure 4). This location was selected because of the continuous and thick sedimentary rock exposed in these rivers. There are a 195-meter continuous outcrop on Cimanuk River and a 285 -meter of that on Cinambo River, in which the details of the sediment layers are measured and described in this study. The result of the analysis of this continuous outcrop was classified and identified into facies associations using the Stow classification (1985).

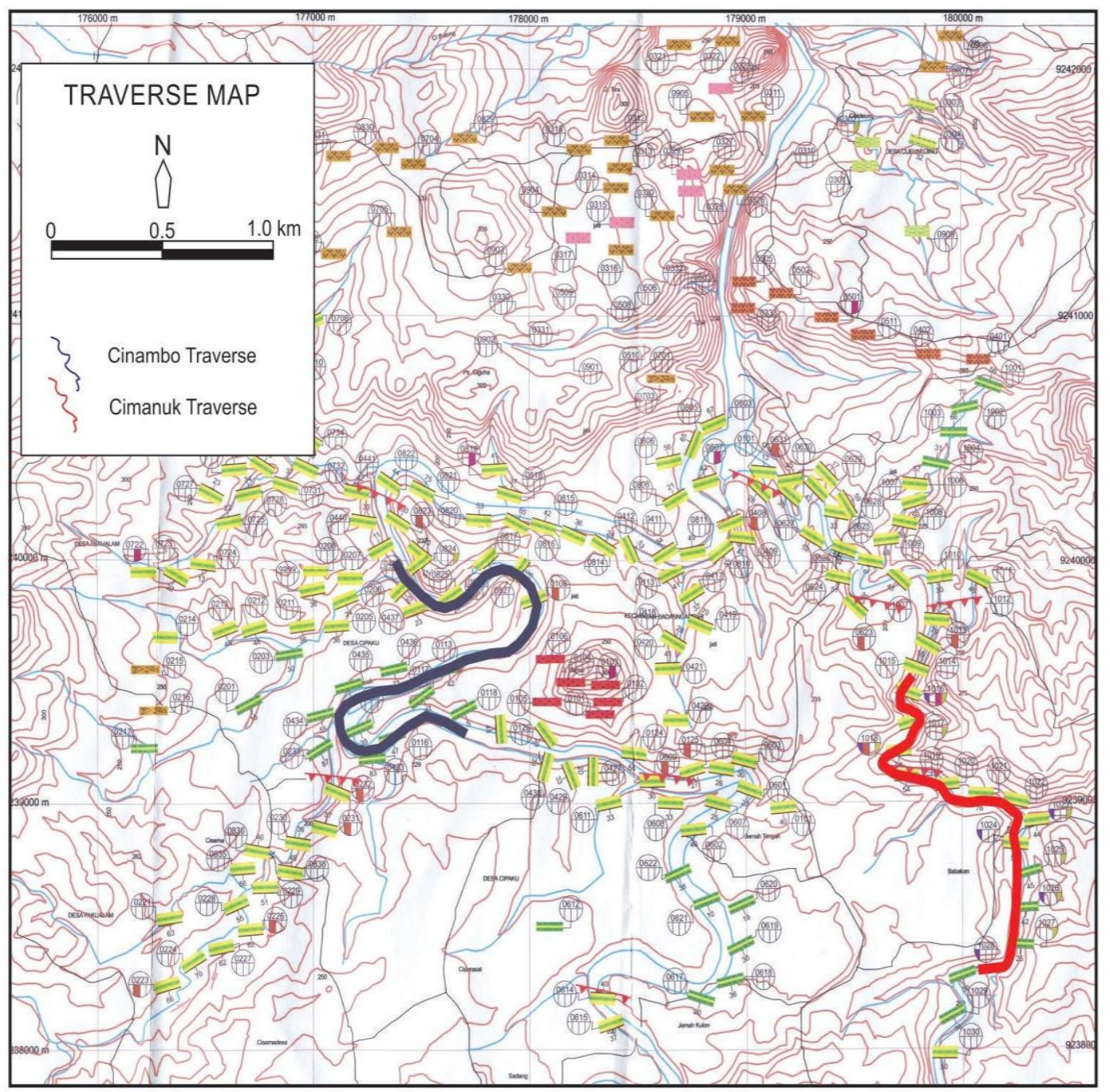

Figure 4. Traverse map of the study area

\section{Result}

\subsection{Lithofacies}

Lithofacies determination in this study refers to the Stow's classification (1985, in Reading, 1996), where the classification of lithology is simplified based on field data collected from Cinambo and Cimanuk traverses (Figure 5, 6). Lithofacies Classification is divided into classes and groups based on it grain size and is further divided into class A-E. Class A consists of sediment of coarse-grain sand to boulder. Class B consists of medium to coarse grained sand. Class C is Silt while Class D is Silt to mud grained sand and Class E is mud sediment with fine sand intercalation (Figure 8). This group division is based on the sedimentary structure, lithological composition, 
sedimentary texture, and thickness of the layer.

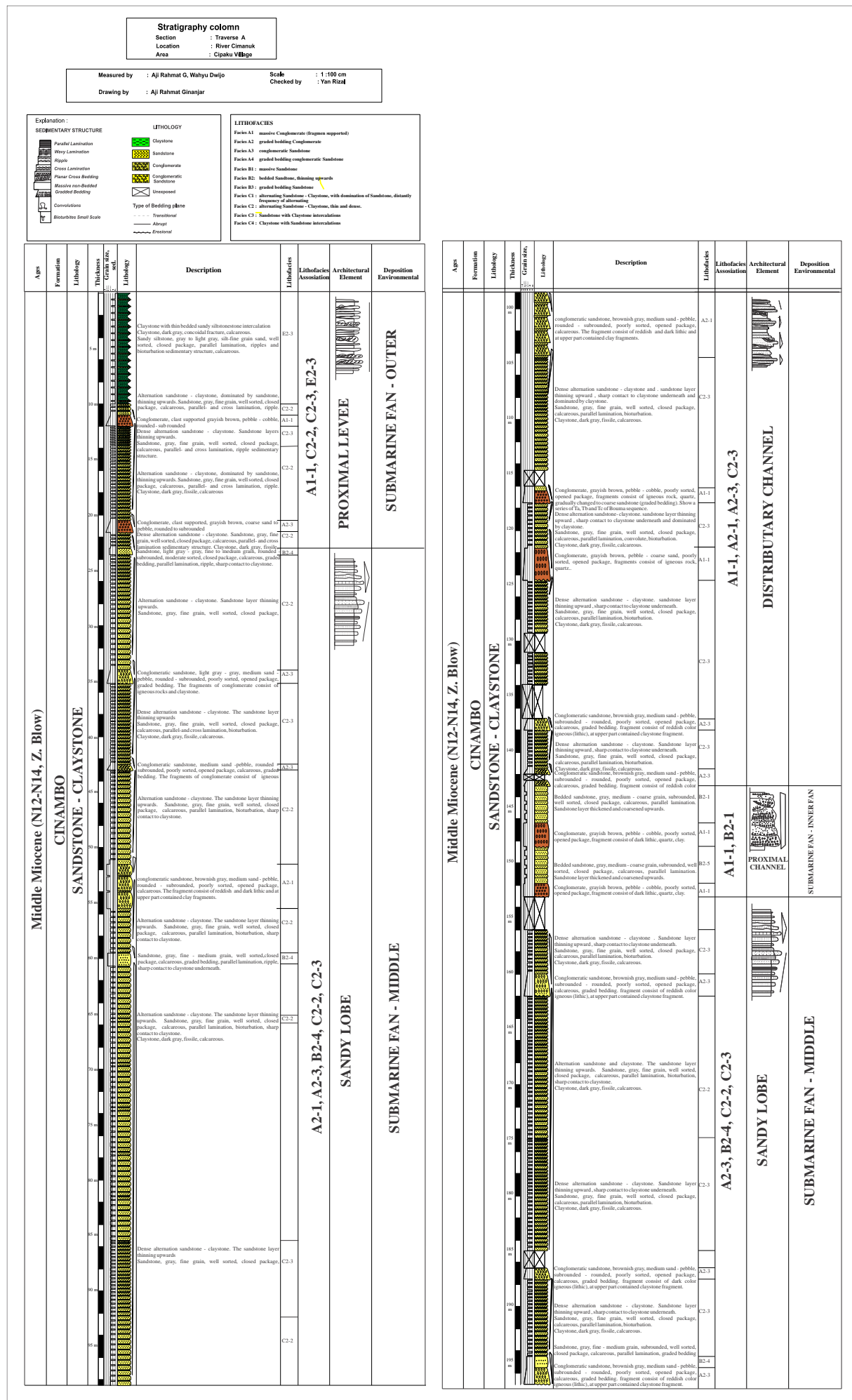

Figure 5. Stratigraphy section of Cimanuk River Traverse 


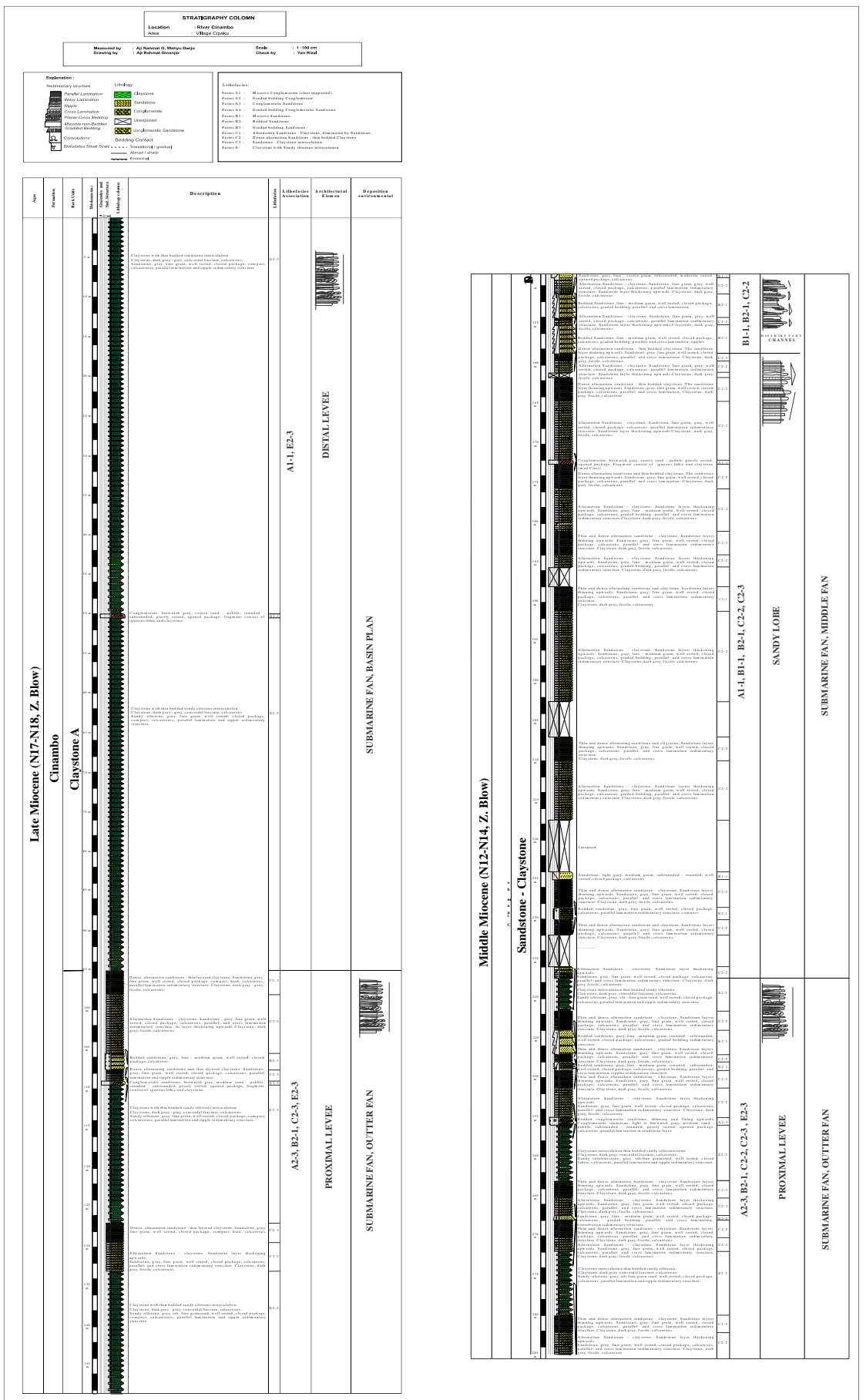

Figure 6. Stratigraphy section of Cinambo River Travers

\subsubsection{Massive Conglomerate Lithofacies (Lithofacies A1-1)}

Lithofacies A1 are massive brownish gray conglomerates, pebble to boulder size, rounded, poorly sorting, open packs, black lithic rock fragments, quartz, and mud, calcareous (Figure 7a). The thickness of the layers varies between 0.5-2 meters. These lithofacies can be found in both traverses (Cimanuk and Cinambo River) although they are rare in Cinambo River.

\subsubsection{Graded Bedding Conglomerate \& Conglomeratic Sandstone (Lithofacies A2-3)}

Lithofacies A2-3 are conglomerates that have a graded bedding sedimentary structure, brownish gray, coarse sand to pebble size, rounded, poorly sorting, open pack, black lithic fragments, quartz and mud, calcareous (Figure 8). 
Coarse sandstones can sometimes be found at the upper region with the $\mathrm{Ta}, \mathrm{Tb}, \mathrm{Tc}$ interval of Bouma sequences. Layer thickness varies between 1-4 meters.

Lithofacies A2-3 present in the form of conglomeratic Sandstones with graded bedding sedimentary structure, gray, coarse sand to pebble sized, rounded, poorly sorting, open packs, black and red lithic fragments, quartz, and mudstone fragments present at the upper part, calcareous (Figure 7b).

\subsubsection{Conglomeratic Sandstone Lithofacies (Lithofacies A2-1)}

Lithofacies A2-1 consist of conglomeratic Sandstone, coarse-grained sand to pebble, rounded, poorly sorting, open packs, black and red lithic fragments, quartz, and mudstone fragments at the upper part, calcareous (Figure 7c). Thickness of the layers is varied between 0.5-4 meters. These Lithofacies are present on both Cimanuk River as well as Cinambo River traverses.

\subsubsection{Massive Sandstone lithofacies (Lithofacies B1-1)}

Lithofacies B1 consist of massive gray sandstone, fine-coarse grained sand, rounded, moderate sorting, open pack, calcareous, parallel lamination sedimentary structure, and trace fossil (Figure 7d). These Lithofacies can be found on both traverses (Cimanuk and Cinambo River).

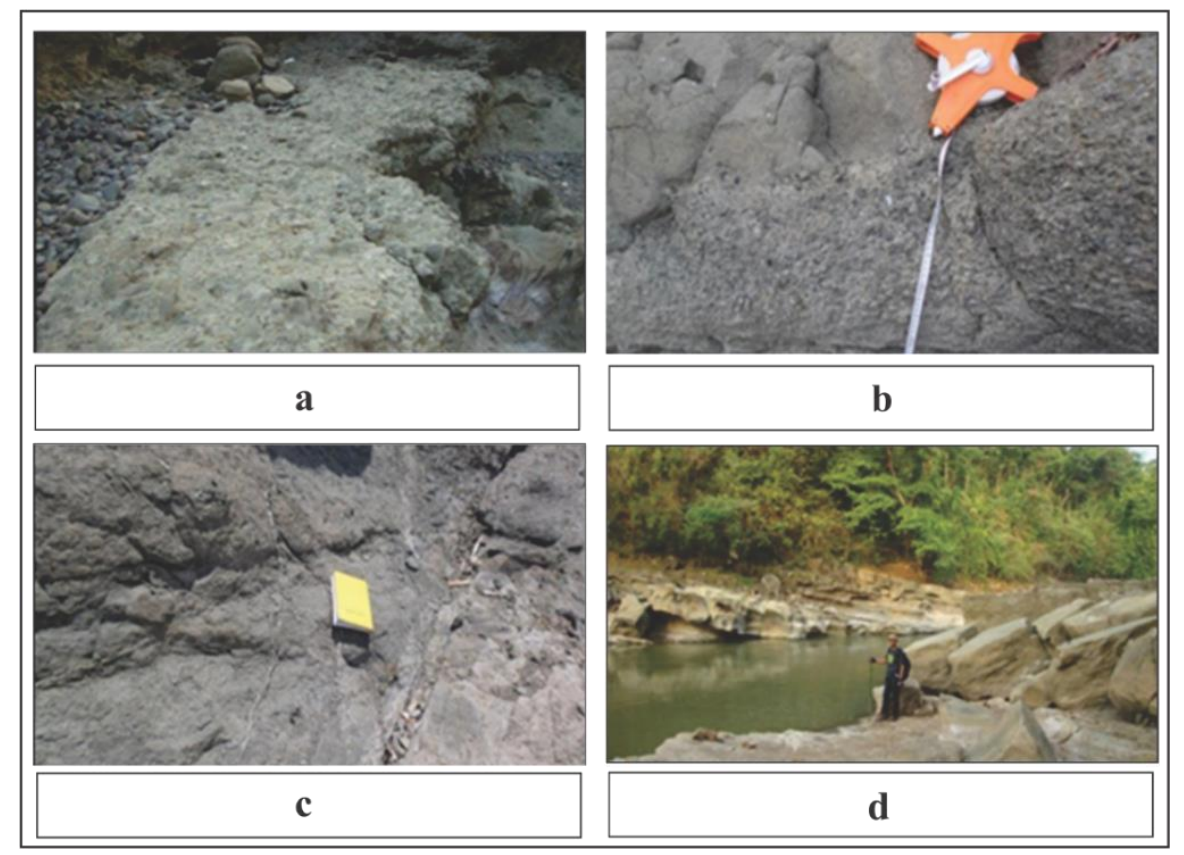

Figure 7. a) Massive conglomerate lithofacies. b) Graded bedding Conglomerate Lithofacies. c) Conglomeratic Sandstone Lithofacies. d) Massive Sandstone Lithofacies

\subsubsection{Graded bedding Sandstone Lithofacies B2-4)}

Lithofacies B2-4 consist of graded bedding Sandstone, gray, fine-coarse grained sand, rounded, moderate sorting, open packs, calcareous, other sedimentary structures are parallel lamination, cross lamination, trace fossils (Figure 8a). The layers thickness varies between 0.5-4 meters. These Lithofacies are found on both sections (Cimanuk River and Cinambo River).

\subsubsection{Lithofacies bedded Sandstone (Lithofacies B2-1)}

Lithofacies B3 is consists of gray sandstone, gray, medium to coarse grained sand, rounded, well sorting, closed packs, calcareous with parallel lamination, cross lamination sedimentary structures (Figure 8b). The layer thickness varies between 0.5-4 meters. These lithofacies are present on both Cinambo and Cimanuk River traverses, but they present in a large quantity along the traverse of Cinambo River.

3.1.7 Lithofacies alternation Sandstone - mud stone (Lithofacies C2-2)

Lithofasies C2-2 consist of interbedding Sandstone and mudstone, although the interbedding is mainly dominated by sandstone. Sandstones, gray, fine to medium grain sand, round, well sorting, closed packs, calcareous, parallel 
lamination, cross lamination sedimentary structures, as well as trace fossils can also be found, with $\mathrm{Ta}, \mathrm{Tb}, \mathrm{Tc}$ interval of Bouma section. Sandstone layers in the figure blow shows an upward thickening of the Lithofacies (Figure 8c). It can also be seen below that the Mudstone is dark gray, brittles and calcareous. The sandstone to mudstone ratio is around 3:1 to 4:1. These lithofacies mostly appear on the upper and lower part of the Cimanuk River, but they are also present in the lower and middle part of the Cinambo River.

\subsubsection{Lithofacies dense and Thin Alternation Sandstone - mudstone (Litofasies C2-3)}

Lithofacies C2-3 consists of alternating Sandstone and mudstone, with special layer characteristics being thin and dense, and the ratio of sandstone-mudstone in between of 2:1 to 1: 1 (Figure 8d). Sandstones, medium to fine grain sizes, rounded, well sorting, closed packs, calcareous with sedimentary structures such as parallel lamination, cross lamination, convolute, bioturbation, and shown a Tc, Td, Te Bouma intervals. Mudstone has dark gray color, brittle, calcareous. These lithofacies are spread evenly across the Cimanuk River, and they can also be found on the middle and lower section of the Cinambo River.

\subsubsection{Lithofacies Mudstone with sandy Siltstone Intercalation (Lithofacies E2-3)}

The Lithofacies C2-3 consists of fine-grained sediment that are dominated by mudstone with sandy siltstones present as insertions. The sandy siltstone layers thin upwards and the ratio of sandy siltstone to mudstone varies from 1:4 to 1:5 (Figure 8e). Sandy siltstone is gray, silt - fine sand grain, rounded, well sorting, closed package, calcareous, sedimentary structure is parallel lamination, cross lamination, ripple, and bioturbation. Meanwhile, Mudstone is dark gray, brittle, and calcareous. These lithofacies are very common along the Cinambo River section. On the Cinambo traverse, the lithofacies found at the upper part are commonly associated A1-1 lithofacies while those found at middle part are associated with lithofacies A2-3, B2-1 and C2-3 and on the Cimanuk River traverse, the lithofacies are commonly $10 \mathrm{~m}$ thick and are associated with lithofacies A1-1, C2-2 and C2-3.

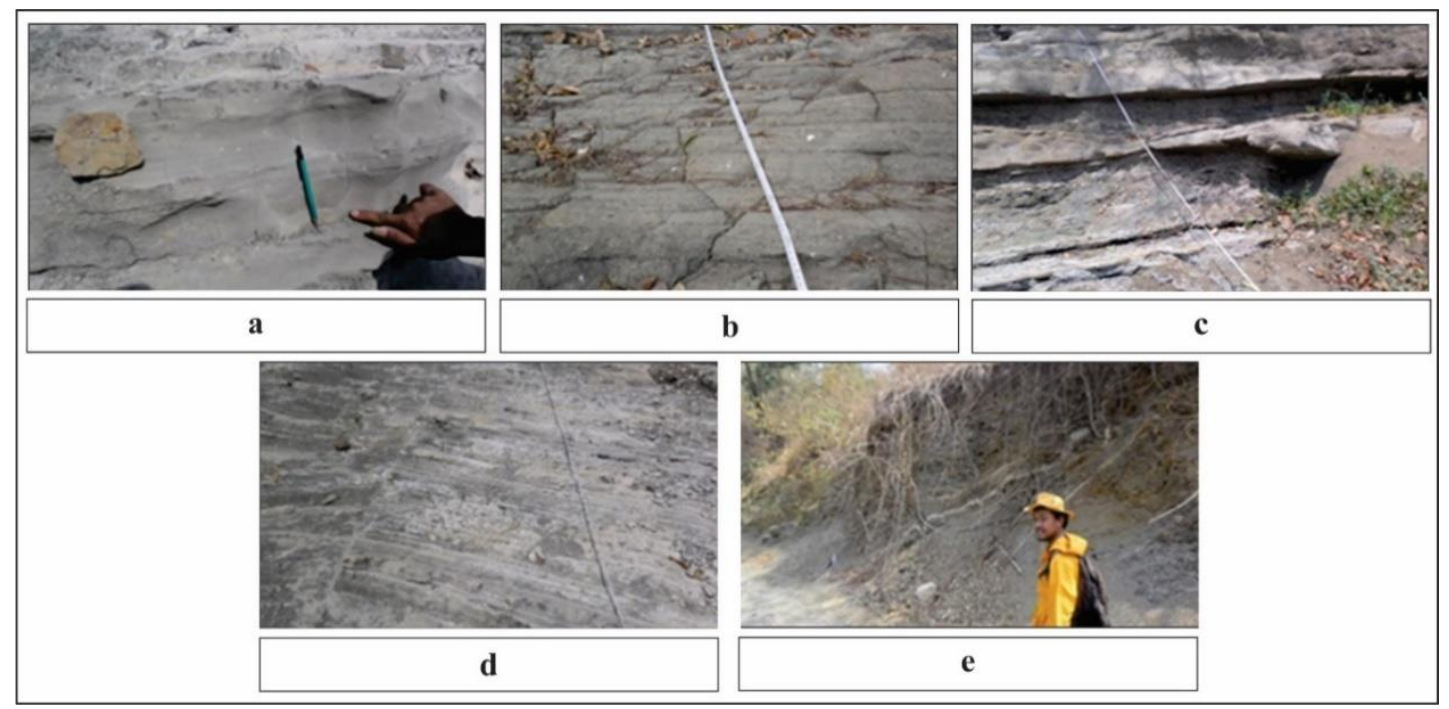

Figure 8. a) Graded bedding sandstone Lithofacies. b) Lithofacies bedded Sandstone. c) Lithofacies alternation Sandstone - mudstone. d) Lithofacies Dense and Thin Alternating Sandstone and Mudstone. e) Lithofacies Mudstone with Sandy Siltstone Intercalation.

\subsection{Architectural Elements}

Architectural elements are morphological subdivisions of a particular depositional system characterized by distinctive assemblages of facies, facies geometries, and depositional systems (Walker and James, 1992). Architectural elements approaches are done interpretatively. Stow and Miall (2000, in Mudler, 2011) list different architectural elements that often appear in the deep marine sediment.

The data collection is based on Miall's concept (1995, in Mulder, 2011), namely:

- The nature of bedding plain contact (erosional, gradual, planar, regular or irregular).

- External geometry (lenses, wedges, sheets, concave-ups)

- Three-dimensional geometry (thickness, laterally and vertically distribution

- Internal geometry (lithofacies association, sedimentary structure) 


\subsubsection{Proximal Channel}

Architectural elements of proximal channel are dominated by gravelly coarse sand - gravel facies (lithofacies A and lithofacies B). Based on the lithology characteristic, this architectural element is interpreted as a product of debris flow mechanical process (Middleton and Hampton, 1976, in Reading, 1996). Mutti and Ricci Luchi (1972, in Reading, 1996) incorporate this architectural element into the association of upper fan depositional environment. A common feature of proximal channel architectural elements according to Reading (1996) is that there is a negative contour, filled sediment with chaotic sedimentary structure and sometimes encountered slump, resulting from sliding or slumping process. This architectural element is found only in the middle interval of the Cimanuk River section.

\subsubsection{Distributary Channel}

Distributary Channel architectural elements are dominated by coarse gravel-gravel facies (lithofacies A and lithofacies B) and lithofacies C. Based on its lithological characteristics, these architectural elements are interpreted as a product of debris flow mechanical process (Middleton and Hampton, 1976, in Reading, 1996). The dominant lithology of this Lithofacies are coarse-grained sand (lithofacies A and B) with fining- and coarsening upward as well as thinning upward sedimentary structure.

Mutti and Ricci Luchi (1972, in Reading, 1996), incorporate this architectural element into the association of the middle fan depositional environment. A common feature of channel architectural elements according to Reading (1996) is that there is a negative contour relief, usually filled with coarse-grained sediments and blocks, massive sandstones and conglomeratic sand, erosional contacts, and channel which can consist of one main channel or meandering channel. This architectural element is only found in the middle interval of the Cimanuk River section

\subsubsection{Sandy Lobe}

The sandy lobe architectural elements are dominated by lithofacies $\mathrm{C}$ (thin and dense interbedded sandstones and mudstones) and lithofacies B (fine-to medium grained sand). Based on its lithology characteristic, this architectural element is interpreted as product of low-density turbidity current (Middleton and Hampton, 1976, in Reading, 1996).

The mechanism of low-density turbidity current is the final phase of the high-density turbidity current. In general, the buildup pattern of this architectural element is initiated from the deposition of $\mathrm{C}$ lithofacies and then followed by the deposition of lithofacies B. Vertical succession of this architectural element is fining upward and thinning upward. Sandy lobe architectural elements is also defined by the low relief morphology, usually located at the end of a channel and consists of medium to fine-grained sediments resulting from the accumulation of one or more classical turbidite lithofacies.

Mutti and Ricci Lucchi (1972, in Reading, 1996) incorporate this architectural element into the final part of the middle fan depositional environment association. This architectural element can be found at the upper and lower intervals of the Cimanuk River sections. It can also be found in the middle interval of the Cinambo River section.

\subsubsection{Proximal Levee}

Proximal levee architectural elements are dominated by facies $\mathrm{C}$ (tight and thin sandstone-mudstone interbedded) and facies $\mathrm{E}$ (mudstone with sandstone intercalation). Based on its lithological characteristics, this architectural element is deposited as a product of low-density turbidity current mechanism (Middleton and Hampton, 1976 in Reading, 1996). In general, the buildup pattern of this architectural element is initiated by the deposition of lithofacies $\mathrm{C}$ which is then followed by the deposition of lithofacies $\mathrm{E}$, with insertions of lithofacies $\mathrm{B}$ commonly found in between these two. Vertically, this architectural element fines up and thins upward. Laterally, facies D thickened and $\mathrm{C}$ facies diminished.

The proximal levee architectural element is the result of an overflow of sediment from a channel (Reading, 1996), which is characterized by fine grain sandstones as well as monotonous and thin interbedded sandstones and mudstones. Mutti and Ricci Lucchi (1972, in Reading, 1996) incorporate this architectural element into lower fan depositional environment association. On Cimanuk River traverse, this architectural element can only be found in the upper section, while on the Cinambo River traverse, they can be found in the upper and middle section (Figure 5 and 6$)$.

\subsubsection{Distal Levee}

The distal levee architectural element is dominated by facies $\mathrm{E}$ (mudstone with sandy siltstone intercalation). Based on its lithological characteristics, this architectural element is deposited as a product of low-density turbidity current mechanism (Middleton and Hampton, 1976 in Reading, 1996), dominated by mudstone lithofacies 
(lithofacies E). This architectural element is deposited in a distal part of a deep marine fan system, where the sediment is dominated by very fine fractions. Mutti and Ricci Luchi (1972, in Reading, 1996) grouped these architectural elements into basin plain environmental association. This architectural element is not found section of Cimanuk River traverse, but they are present at the upper interval of the Cinambo River section (Figure 5 and 6).

\section{Discussion}

On the sketch of the cross-section of East West from each structural element on Cinambo- and Cimanuk River traverses showing the lateral relationships each structural element corresponds to the time of it deposition (Figure 9 and 10). On the Cimanuk River traverse, sedimentation of Cinambo Formation is started from deposition of turbidite series of sandy lobe sediment (Facies A, B, and C). Meanwhile on the Cinambo River traverse, a sediment of proximal levee is deposited which is close to the basin plain, marked by the appearance of Claystone interbedded by sandy Siltstone (Facies E) (Figure 9-1 and Figure. 10-1). This change can be interpreted laterally as a change in facies, where the position of the sediment found on the Cinambo river traverse is deeper than the position of the sediment found on the Cimanuk river. These lithofacies are covered by relatively coarse grain sediment of channel, which washed out an older architectural element and formed a new channel in Cimanuk section and in Cinambo section still continued a deposition of proximal levee (Figure 9-2 and Figure 10-2) and interpreted the sea level is dropped which caused a new vertical erosion in Cimanuk traverse. This unit is covered by deposits of the tributary channel in either the Cimanuk or Cinambo section (Figure 9-3 and Figure 10-3) (regression phase). On Cimanuk section, architectural element changed from a tributary channel to sandy lobe, and on the Cinambo section shifted an environment deposition from proximal levee to sandy lobe (Figure 9-4 and Figure 10-4), it interpreted as product of sea level rise or subsidence. The sea level rise or subsidence keep continued, that indicated change of architectural elements on Cimanuk River section from sandy lobe to proximal levee and on the River Cinambo changed architectural elements from sandy lobe to distal levee (Figure 9-5 and Figure 10-5) (transgression phase).

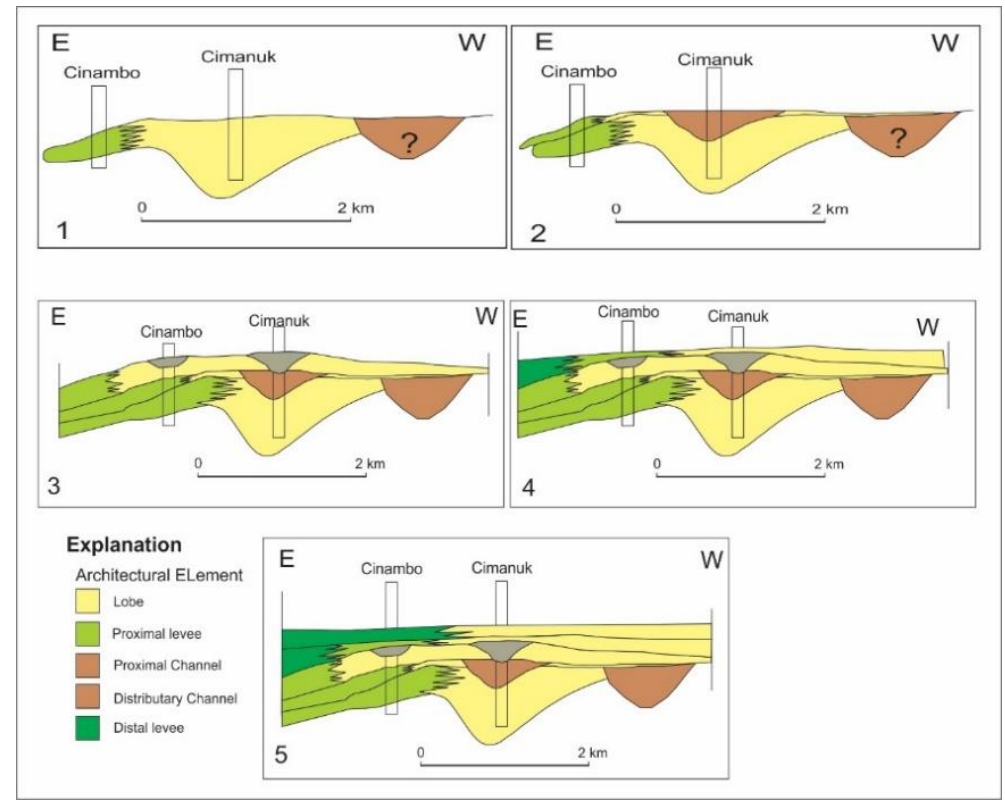

Figure 9. Sketch of development of architectural element position of Cimanuk- and Cinambo River Traverses 


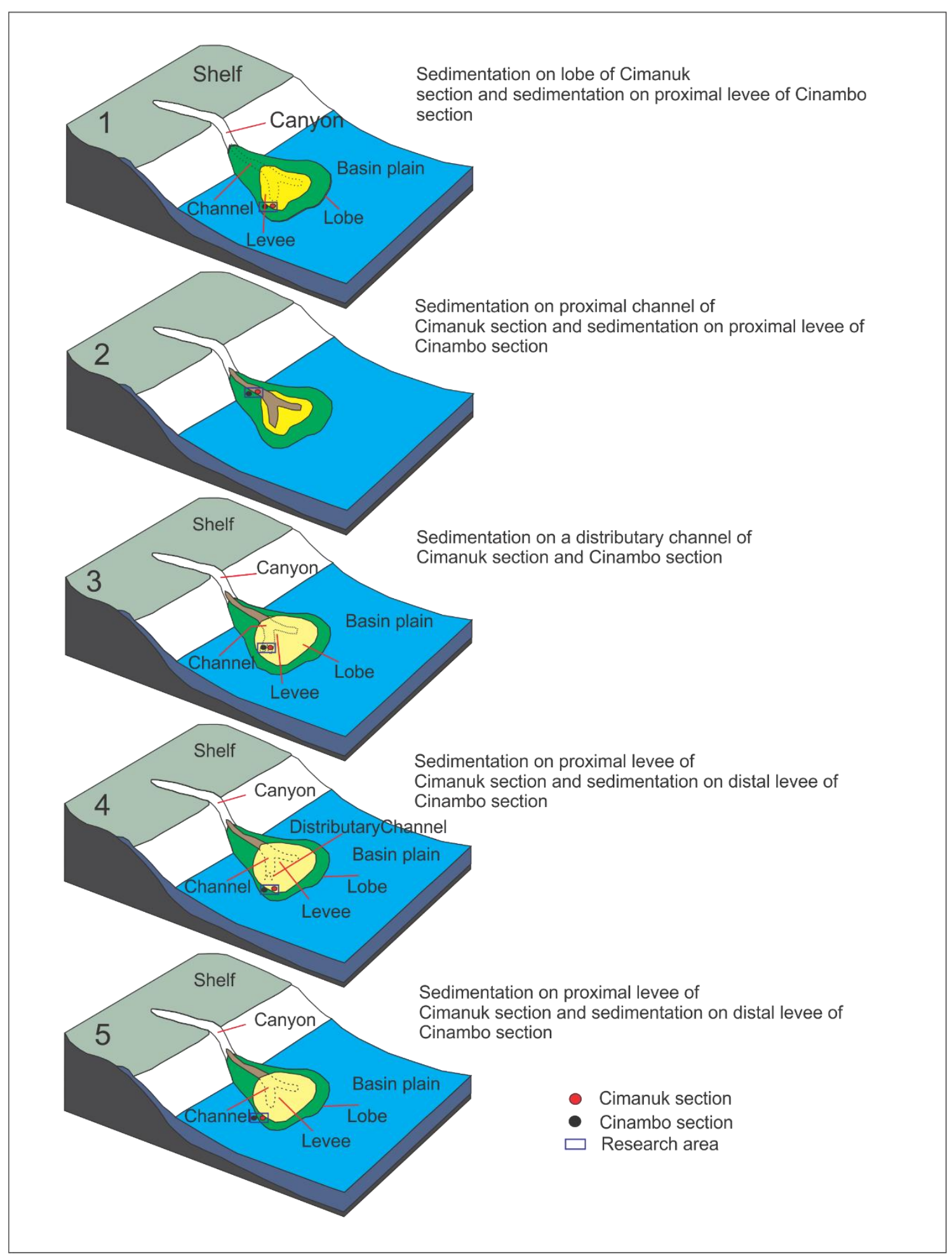

Figure 10. Sketch of morphology development of architectural element position of Cimanuk- and Cinambo River Traverses

The change in depositional environment that occurs during the deposition of rock units of the Cinambo Formation which is interpreted as a result of sea level change, is clearly seen in relation to the sea level change curve made by Haq (1987) in Miller et al. (2005) which occurs in the Middle-Late Miocene (Figure 11). 


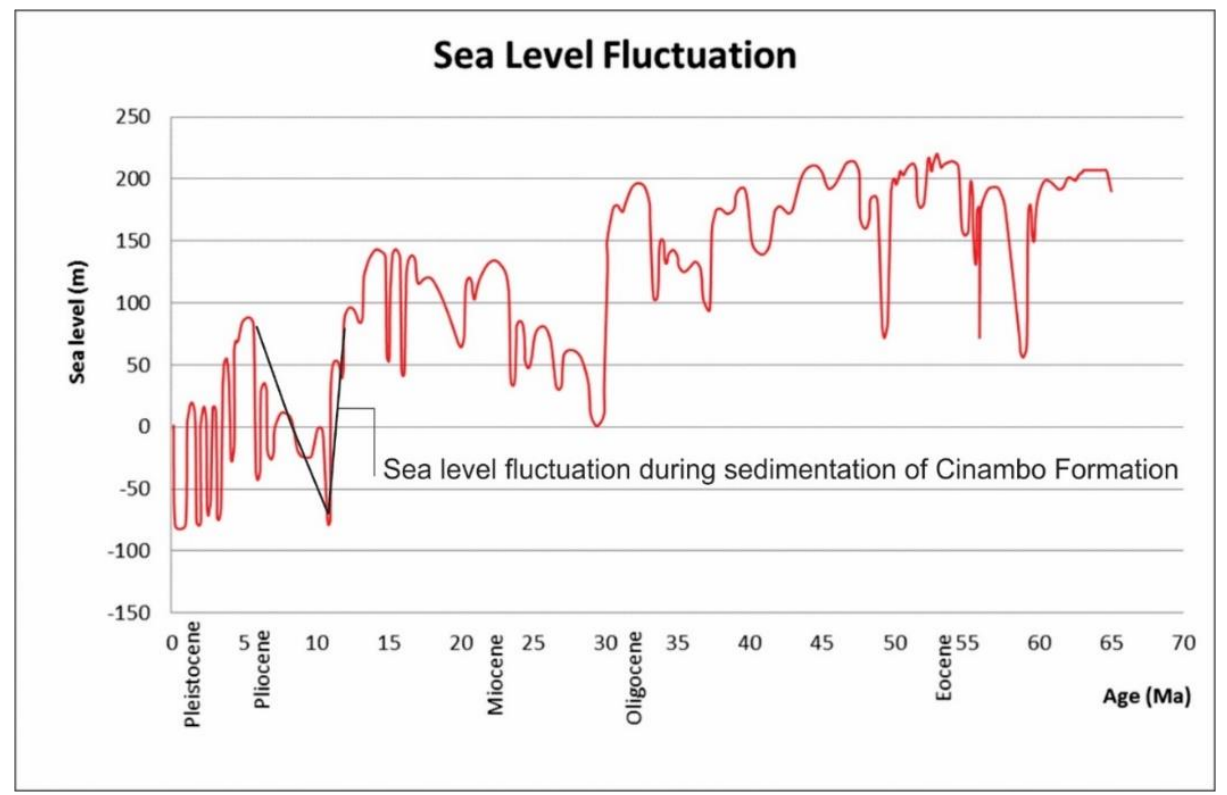

Figure 11. Sea level Fluctuation during Cenozoic (Modified from Hag in Miller, et al 2005)

\section{Conclusion}

Base on above description can it can be concluded that:

The lithofacies, which were found on the Cimanuk River traverse according to Stow Classification (1985) are lithofacies A1-1, A2-1, A2-3, B2-1, B2-4, C2-2 and C2-3 as well as E2-3, with architectural element of sandy lobe, proximal channel, distributary channel, and proximal levee. The lithofacies on the Cinambo River traverse consist of lithofacies A1-1, A2-3, B1-1, B2-1, C2-2, C2-3 and E2-3 with architectural element of sandy lobe, distributary channel, proximal levee and distal levee. A vertical change of the architectural element can be observed on both traverses, which are likely to be caused by the fluctuation of sea level (regression and transgression phase).

\section{References}

Djuhaeni \& Martodjojo, S. (1988). Stratigrafi Daerah Majalengka dan hubungannya dengan Tatanama Satuan Litostratigrafi di Cekungan Bogor, Geologi Indonesia. PPPG-Bandung, 12(1), 227-252 (in Indonesian).

Djuri (1973). Peta Lembar Geologi Arjawinangun, Skala 1:100.000, Pusat Penelitian dan Pengembangan Geologi (in Indonesian).

Koesoemadinata, R. P., \& Martodjojo, S. (1974). Penelitian turbidit di Pulau Jawa. Laporan Penelitian No. 1295/74, Badan Penelitian, Insitut Teknologi Bandung.

Kusumastuti, A., Mortimer, A., Todd, C., Guritno, E., Goffey, G., \& Bennet, M., et al. (2001). Deep-water petroleum provinces of Southeast Asia: A high level overview. Indonesian Sedimentologist Forum, 2nd regional seminar, p. 10-15.

Martodjojo, S. (1984). Evolusi Cekungan Bogor, Jawa Barat (Unpublished doctoral dissertation), ITB, Bandung (in Indonesian).

Miller, K. G., Michelle, A. K., \& James, V. B. et al. (2005). The Phanerozoic Record of Global Sea-Level Change, Science 310, 1293-1298.

Mulder, T. (2011). Gravity Processes and Deposits on Continental Slope, Rise and Abyssal Plains. in Deep Sea Sediment, Chapter 2, Elsevier, van Loon, A. J., Editor, Oxford, 25-148.

Nugrahanto, K., McFall, S. W., \& Estella, F. (2001). Submarine-fan deposition in the lower Steenkool Formation, Bintuni Basin, Irian Jaya, Eastern Indonesia: "Deep-Water Reservoir Potential?" Proceedings Deep-Water Sedimentation of Southeast Asia, FOSI, 2nd Regional Seminar, p. 66-84.

Praptisih, Siregar S., Kamtono, Hendrizan, \& Putra, P. S. (2012). Fasies Dan Lingkungan Pengendapan Batuan Karbonat Formasi Parigi Di Daerah Palimanan, Cirebon. Jurnal Riset Geologi dan Pertambangan, 22(1), 3343. LIPI, Bandung. http://www.doi.org/10.14203/risetgeotam2012.v22.56 
Reading, H. G. (1996). Sedimentary Environments: Process, Facies and Stratigraphy. Blackwell Publishing, Oxford.

Rizal, Y., Lagona, R., \& Santoso, W. D. (2017). Turbidite Facies Study of Halang Formation on Pangkalan River, Karang Duren - Dermaji Village, Banyumas District, Central Java. Indonesia, IOP Conference Series: Earth and Environmental Science, 71(1), 1-17.

Rizal, Y., Santoso, W. D., Rudyawan, A., \& Tampubolon, R. A. et al. (2018). Sedimentary Facies and Hydrocarbon Reservoir Potential of Sand Flat in The Upper Part of Tapak Formation in Banyumas Area, Central Java. Riset Geologi Pertambangan, 2(2), 251-263.

Rizal, Y., Waluyo, G., Irawan, S. A., \& Rudyawan, A. (2016). Facies Study of the Halang Formation Turbidites in Cibalung Area, Cimanggu District, Cilacap Regency, Central Java. Indonesia, Journal of Earth Science \& Climatic Change, 7(8), 1-8.

van Bemmelen, R. W. (1949). The Geology of Indonesia, Vol. IA: General geology of Indonesia and Adjacent Archipelagoes. The Hague, Martinus Nijhoff, vol. 1A, Netherlands.

Walker, R. G., \& James, N. P. (1992). Facies Models, Response to Sea Level Change. Geological Association of Canada.

\section{Copyrights}

Copyright for this article is retained by the author(s), with first publication rights granted to the journal.

This is an open-access article distributed under the terms and conditions of the Creative Commons Attribution license (http://creativecommons.org/licenses/by/4.0/). 